\title{
IgG4 関連の難治性慢性鼻副鼻腔炎
}

\author{
太田＼cjkstart康
}

東邦大学医学部耳鼻咽喉科学講座（佐倉）

\section{Refractory chronic rhinosinusitis of IgG4-related disease}

\author{
Yasushi Ota
}

Toho University Medical Center Sakura Hospital

キーワード：慢性鼻副鼻腔炎, IgG4 関連疾患, ミクリッツ病, 自己抗体, デスモグレイン 3

Key words: chronic rhinosinusitis, IgG4 related disease, Mikulicz disease, autoantibody, desmogleins 3

\section{1.はじめに}

IgG4 関連疾患とは, 血清 $\mathrm{IgG} 4$ 高值と罹患臓器への著明 な IgG4 陽性形質細胞浸潤を特徴とする原因不明の慢性炎 症性疾患である。頭頸部領域の IgG4 関連疾患としては, 両側の涙腺，顎下腺の炎症性腫脹をきたすミクリッツ病が

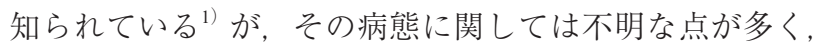
その治療方法は未だ確立されていない2）。近年 IgG4 関連疾 患に合併した慢性鼻副鼻腔炎の報告が散見される ${ }^{3-5)}$ 。今 回, $\mathrm{IgG} 4$ の関与が示唆された難治性の慢性鼻副鼻腔炎の 2 症例を経験したので，ここに報告する。

\section{2. 症例提示}

症例 1 は 47 歳男性である。 2 年前より慢性的に鼻閉, 鼻 漏，咳嗽症状を認めた。1 年ほど保存的に加療したが症状 改善を認めず，当科紹介受診となった。気管支喘息の既往 は無い。初診時鼻内視鏡所見では，両側下鼻甲介粘膜蒼白 であったが，鼻茸などは認められず，中等度の鼻漏，後鼻 漏を認めた。副鼻腔Computed Tomography（CT）では，両 上顎洞の軟部院影, 両篩骨洞の軟部組織院影を認めた （図 1）。血液検査所見では, IgE $100 \mathrm{IU} / \mathrm{ml}$ と正常であり，

2020 年 10 月 18 日受稿

別冊請求先：太田 康

干285-8741 千葉県佐倉市下志津 564-1

東邦大学医学部耳鼻咽喉科学講座 (佐倉)

TEL: 043-462-8811

E-mail: Yasushiota5610@yahoo.co.jp
血中好酸球は $3.7 \%$ と正常範囲であった。鼻症状の改善を なかなか認めないため, IgG4 測定したところ，血清 $\mathrm{IgG}$ $1473 \mathrm{mg} / \mathrm{dl}, \mathrm{IgG} 4306 \mathrm{mg} / \mathrm{dl}$ と， IgG4 高值を示していた。

診断および治療目的に全身麻酔下に両側鼻内視鏡下鼻副 鼻腔手術を施行したところ，左上顎洞には膿汁の貯留を認 めたが，篩骨洞上顎洞の粘膜腫脹は両側とも軽度であっ た。手術検体による病理組織検査では, Hematoxylin Eosin （HE）染色でリンパ球，形質細胞や繊維化病変を認め，好 酸球浸潤は少数のみであった。免疫組織染色では IgG/IgG4 比 $40 \%$ 以上，強拡大で 10 個以上の $\operatorname{IgG}$ および $\operatorname{IgG} 4$ 陽性形 質細胞を認め（図 2:1-3）, IgG4 関連疾患の包括的診断基 準を満たした。IgG4 関連疾患が考えられたため，全身検 索を行ったが, 眼窩外側部の腫脹や唾液腺腫脹の出現はな く, 全身 CTでも他臓器に IgG4 関連疾患を示唆する所見 もなく，病変は鼻副鼻腔だけであった。手術後鼻閉症状は 軽快したが, 鼻腔分泌物の多さは遷延し, 後鼻漏, 咳嗽症 状が継続した。現在鼻洗浄や鼻噴霧型ステロイド，吸入ス テロイド/長時間作用型 $\beta$ 刺激薬（ICS/LABA）配合剤, CAMの少量長期投与などで外来経過観察中である。

症例 2 は 42 歳男性。両側鼻閉，嗅覚消失，両側顎下部 の腫脹で当科を受診した。初診時両側鼻腔に鼻茸が認めら れ (図 3), 両側の顎下部, 眼窩外側部の腫脹も認められた。 CT では両側の沉副鼻腔炎, 両側顎下腺, 涙腺の腫脹が認 められた（図 4)。血液検査では，血清総 IgE $380 \mathrm{IU} / \mathrm{mL}$, IgG4 $383 \mathrm{mg} / \mathrm{dL}$, と高值を示し, 血中好酸球は $6.3 \%$ と正常 範囲内であった。血清抗デスモグレイン 3 抗体は $4390 \mathrm{U} / \mathrm{ml}$ と高值を示した。 


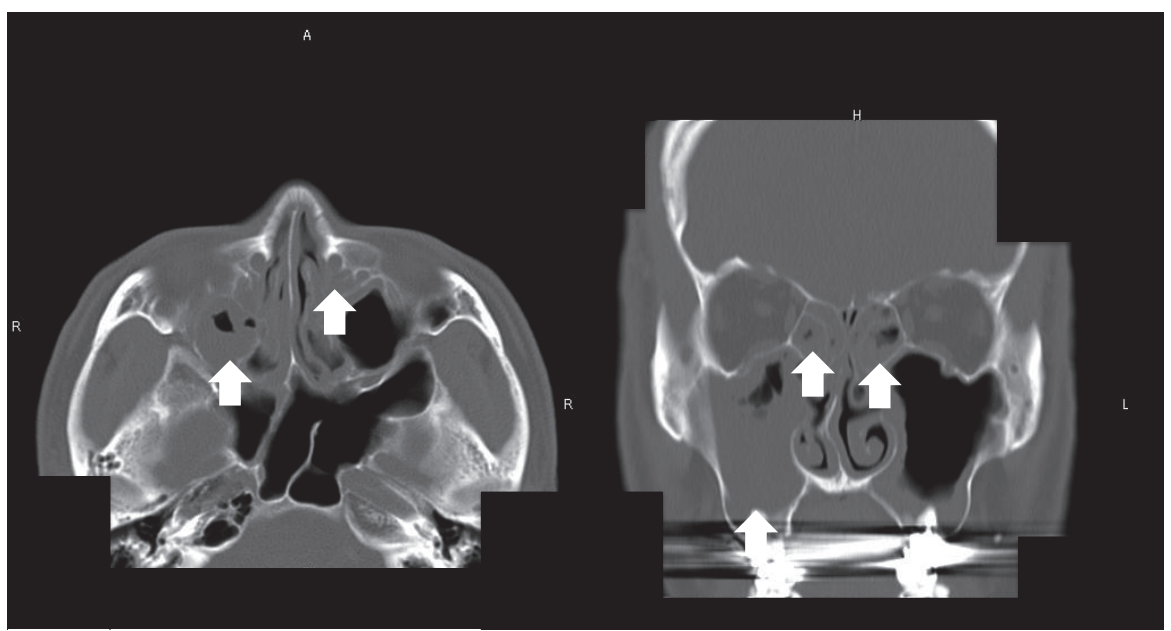

図 1 症例 1 副鼻腔 CT：両上顎洞の軟部陰影，両篩骨洞の軟部組織陰影を認める（白矢印）。(文献 11 より）
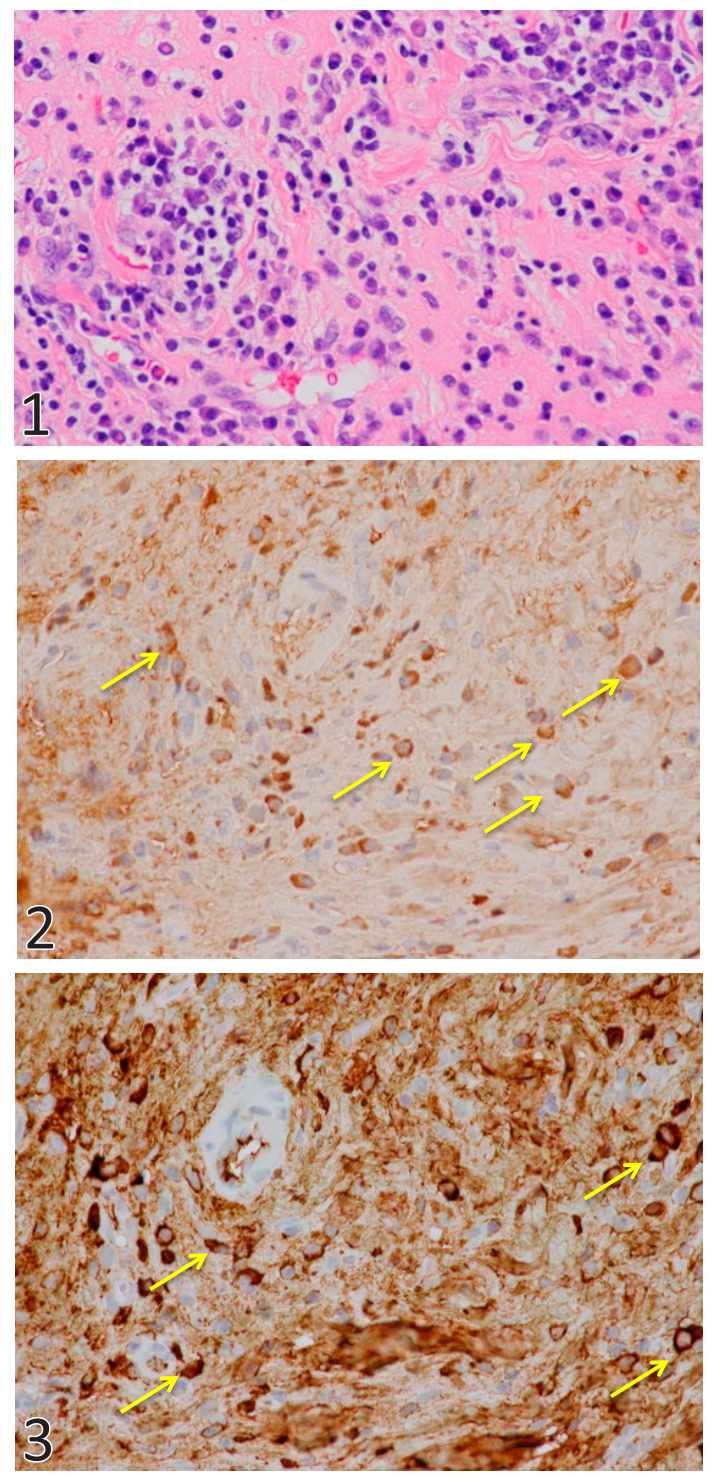

図 2 症例 1 副鼻腔粘膜病理組織写真。1 : HE 染色。2 : 免疫染色 (抗 $\operatorname{IgG}$ 抗体)。3 : 免疫染色 (抗 IgG4 抗体)。 IgG/IgG4 比 $40 \%$ 以上, 強拡大で 10 個以上の $\operatorname{IgG}$ 抢よび IgG4 陽性形質細胞を認める（矢 印)。(文献 11 より)
全身麻酔下で鼻内視鏡下鼻副鼻腔手術，左顎下腺生検術 を施行した。病理組織標本に扔いて, 鼻副鼻腔粘膜固有層 には多数の IgG4 陽性細胞の浸潤が認められた。顎下腺に も多数の $\mathrm{IgG} 4$ 陽性細胞の浸潤が認められ，どちらも IgG4 陽性細胞数 $/ \mathrm{IgG}$ 陽性細胞数 $>50 \%$ であり（図 5), IgG4 関 連疾患の診断基準は満たしていたため, IgG4 関連ミクリッ ツ病とそれに合併する IgG4 関連の鼻副鼻腔炎と診断した。 好酸球浸潤はわずかであった。術後は, 抗ロイコトリエン 薬，ステロイド鼻噴霧薬で経過をみているが，手術後 3 年 現在，鼻粘膜に癒着性腫脹が認められ，嗅覚脱失は持続し ている。

デスモグレイン 3 と $\mathrm{IgG} 4$ との関係を調べる為にエライ ザーを施行した。コントロールとして血清 IgG4 正常な慢 性副鼻腔炎症例，血清 IgG4 高值の慢性副鼻腔炎症例の血 清を用いて，同様な測定を行った。その結果，本症例の血 清のみ反応が認められ，コントロール症例は反応が認めら れなかった（図 6)。以上から，当症例に打ける IgG4 はデ スモグレイン 3 に対する自己抗体である，と判断した。

同症例の IgG4 染色病理組織標本に打いて, 副鼻腔粘膜 上皮細胞の細胞間隙に沿って IgG4 の染色が認められた。 デスモグレイン 3 で染色してみると，やはり同様に上皮細 胞の細胞間隙に沿って抗デスモグレイン 3 抗体陽性細胞が 存在していた。このことから, IgG4 が副鼻腔粘膜上皮間 隙に存在するデスモグレイン 3 に自己抗体として反応して いると推測した。この症例においては, 慢性副鼻腔炎にお ける難治性の炎症性病変の原因にデスモグレイン 3 に対す る自己抗体 IgG4 が関与していると考えられた（図 7)。

\section{3. 考察}

2 症例とも鼻副鼻腔手術後も鼻症状が持続する難治性の 鼻副鼻腔炎であるが，喘息を合併せず，血中，副鼻腔粘膜 に好酸球浸潤を伴わない非好酸球性鼻副鼻腔炎である。原 


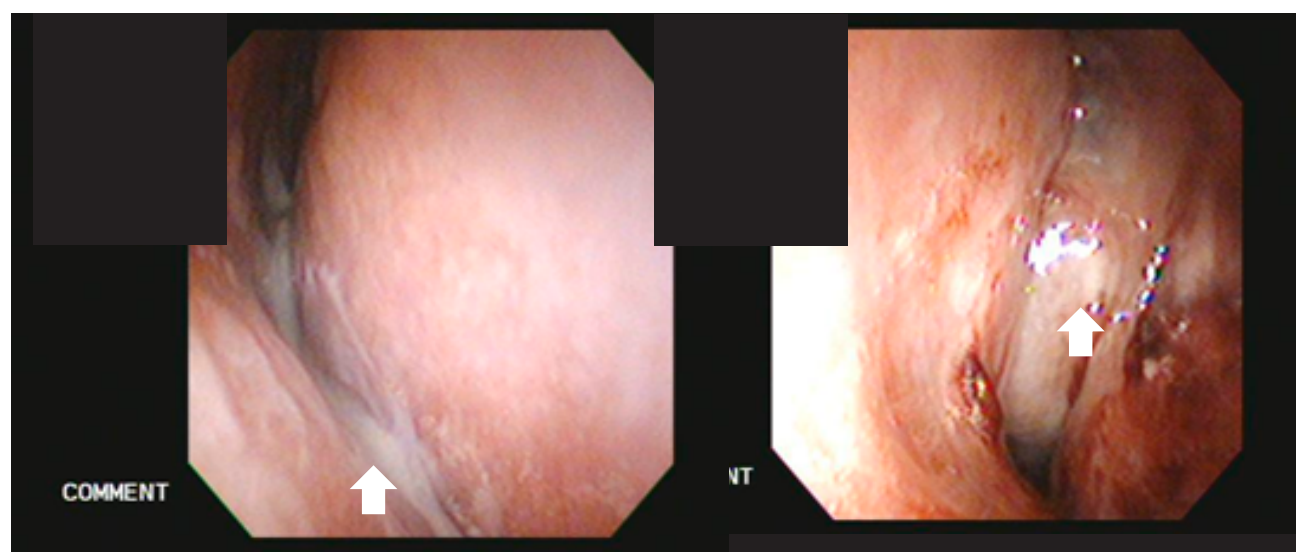

図 3 症例 2 初診時鼻腔ファイバー所見。両側鼻腔に中程度の鼻茸が認められる。(文献 12 より)

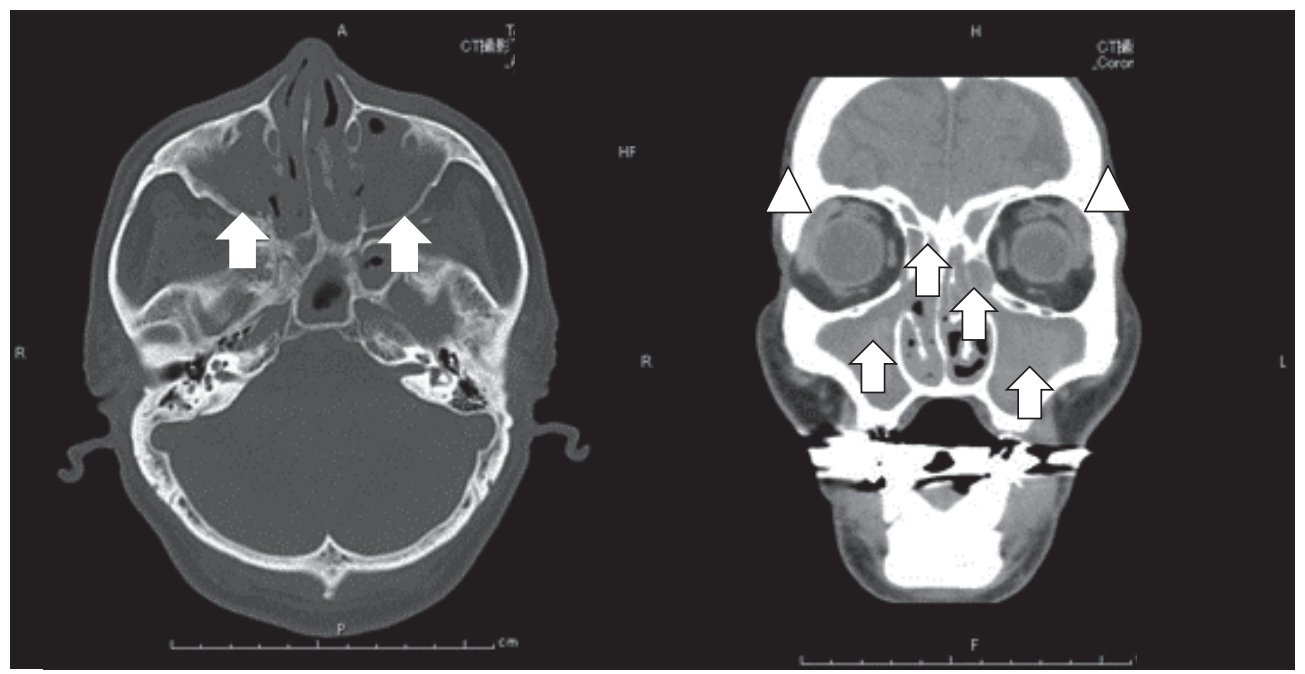

図 4 症例 2 副鼻腔 $\mathrm{CT}$ ：上顎洞，篩骨洞，前頭洞と各副鼻腔に軟部組織陰影を認めた（白矢印）。両側涙腺の腫脹が認められた（白矢尻）。 (文献 12 より)
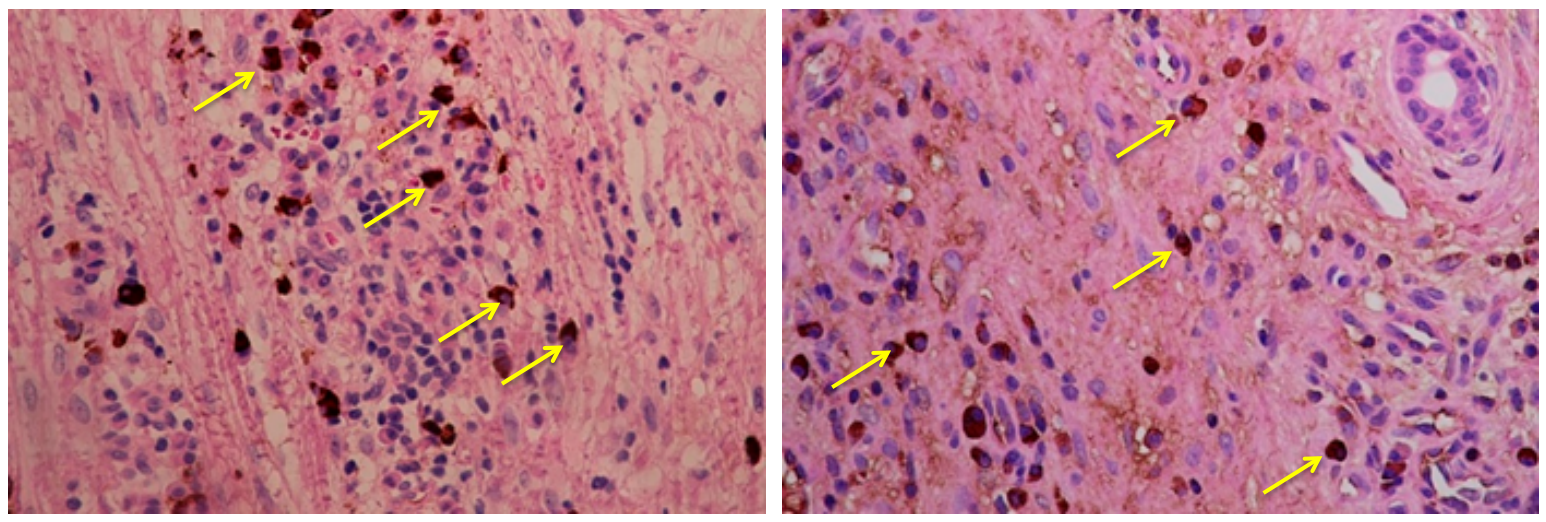

図 5 症例 2 免疫染色（抗 IgG4 抗体）副鼻腔粘膜組織, 顎下腺組織に多数の IgG4 陽性形質細胞を認める（矢印）。（文献 12 より） 


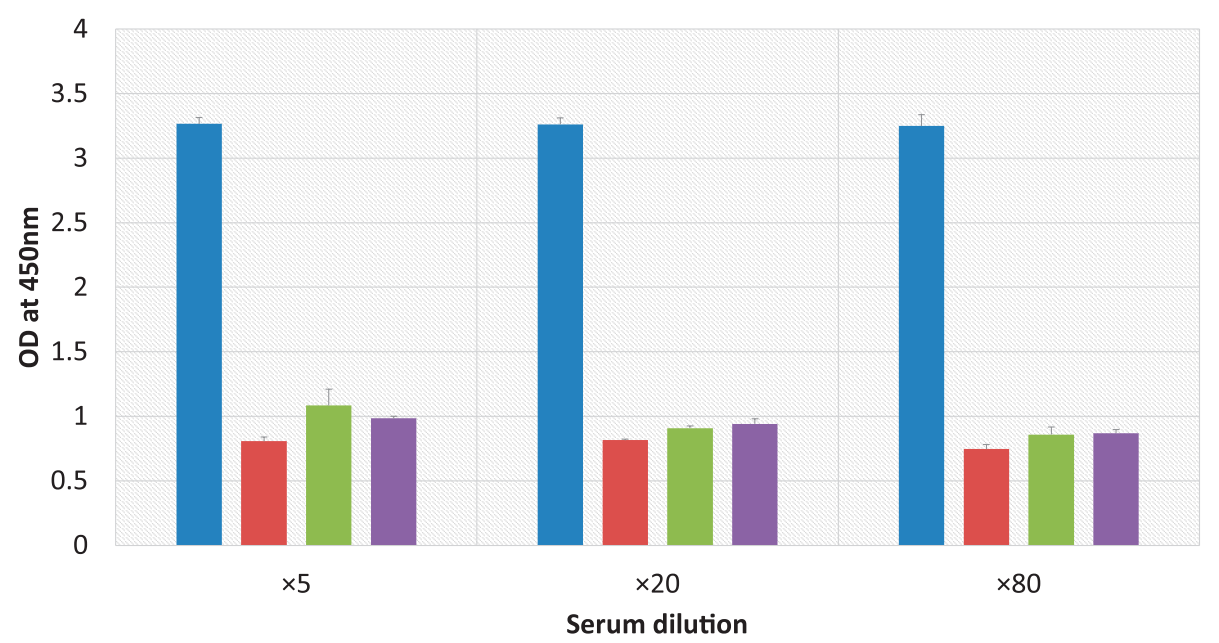

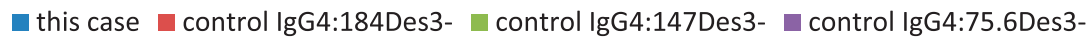

図 6 症例 2 エライザー結果。(文献 12 より)
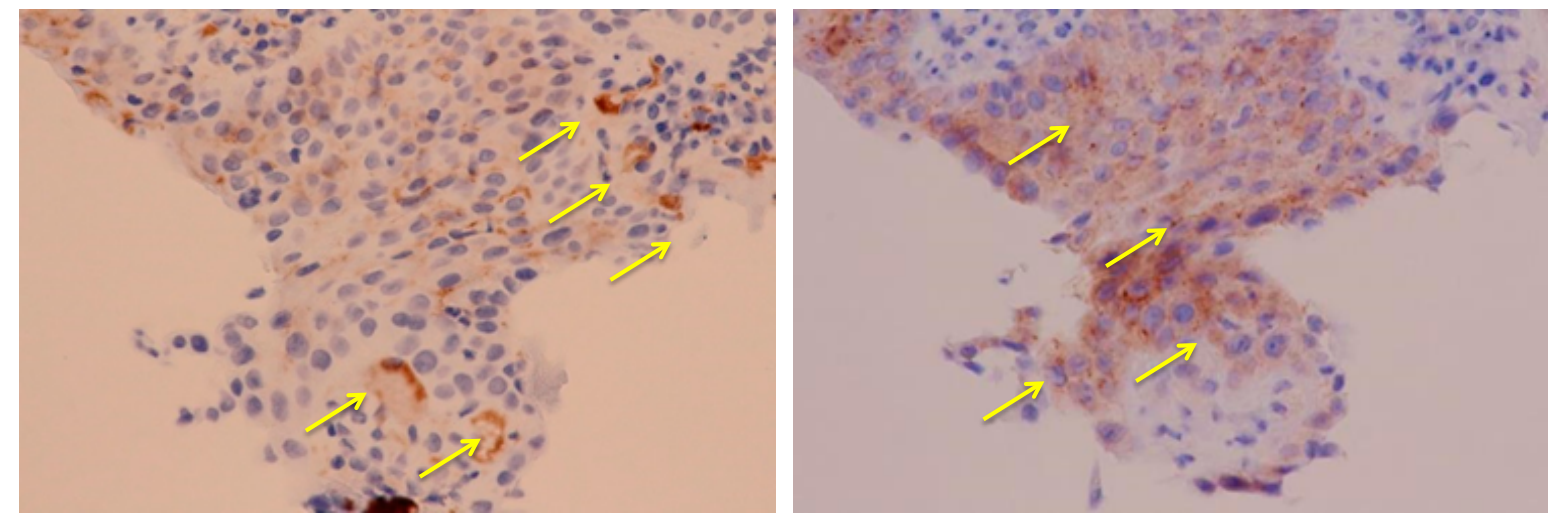

図 7 症例 2 副鼻腔粘膜免疫組織染色写真。抗 IgG4抗体も抗デスモグレイン 3 抗体も粘膜上皮の細胞間隙を中心に染色が認められた (矢印)。 (文献 12 より)

因も好酸球ではなく, IgG, IgG4が関与していると考えら れ，好酸球性鼻副鼻腔炎とはまた別の病態であると考えら れる。

IgG4 関連慢性鼻副鼻腔炎に関しての個別の診断基準は なく, 症例 1 に扔いては Okazaki らが報告した包括的診断 基準（図 8）に基づいて検討した6)。今回鼻腔という単一臟 器に粘膜肥厚が続き, 血液検査では $\mathrm{IgG} 4$ 高值を認め, 病 理検査ではリンパ球や形質細胞の浸潤や繊維化, IgG, IgG4 陽性形質細胞の浸潤を認め, 包括的な診断基準を満 たした。今後は症例の積み重ねにより IgG4 関連慢性鼻副 鼻腔炎の診断基準をより明確にしていくことが必要であ る。また, 慢性副鼻腔炎症例全てに IgG4 に対する検査を 行うことは現実的ではないが, 手術や長期に及ぶ保存的治 療に抵抗する副鼻腔炎症例に扔いては, 血清, あるいは組 織中の IgG4 の検査を行うことは意味のあることであると 思われる。

Takano らは, IgG4関連疾患の $51.9 \%$ に副鼻腔炎を合併し
(1)臨床所見: 単一または複数臓器に, びまん性あるいは 限局性腫大, 腫瘤, 結節, 肥厚性病変を認めること.

(2) 血液所見: 高IgG4 血症 (135 mg/dl 以上)を認めること.

(3)病理学的所見

a. 著明なリンパ球, 形質細胞の浸潤と線維化.

b. IgG4/IgG 陽性細胞比40\%以上かつIgG4 陽性形質細胞 が10/HPF を超えること.

$1+2+3=$ 確診群 (definite), $1+3=$ 準確診群 (probable)， $1+2=$ 疑診群 (possible)

図 8 IgG4 関連疾患の包括的診断基準。(文献 6 より)

ていたと報告している7゙。また，好酸球性鼻副鼻腔炎症例 において, IgG4 浸潤が術後の予後と相関すると報告され ている ${ }^{8)}$ 。今後, IgG4 関連慢性鼻副鼻腔炎と好酸球性鼻副 鼻腔炎との関係, あるいは非好酸球性鼻副鼻腔炎との関係 も明確にしていく必要がある。

$\mathrm{IgG} 4$ 関連ミクリッツ病, あるいは IgG4 関連の慢性鼻副 
鼻腔炎において，その自己免疫性，自己抗原を同定した報 告は他にみられないが, 他領域における IgG4 関連疾患に おいては散見される ${ }^{9,10)}$ 。今回症例 2 でデスモグレイン 3 に対する自己抗体 IgG4 が同定されたことから, IgG4 関連 ミクリッツ病, IgG4 関連の慢性鼻副鼻腔炎においても自 己免疫疾患が関与していると思われる。同時自己抗体 IgG4による自己免疫病態が慢性鼻副鼻腔炎の難治化に関 与している可能性が考えられる。

本論文に関して, 開示すべき利益相反状態は存在しない。

\section{文献}

1) Yamamoto $M$, Ohara M, et al. Elevated IgG4 concentrations in serum of patients with Mikulicz's disease. Scand J Rheumatol. 2004; 33: 432-3.

2) Takano $\mathrm{K}$, Yamamoto $M$, et al. Recent advances in knowledge regarding the head and neck manifestations of IgG4-related disease. Auris Nasus Larynx. 2017; 44: 7-17.

3) Moteki H, Yasuo M, et al. IgG4-related chronic rhinosinusitis: A new clinical entity of nasal disease. Acta Oto-Laryngologica. 2011; 131: 518-26.

4) Ohno K, Matsuda Y, et al. Nasal manifestations of IgG4-related disease: a report of two cases. Auris Nasus Larynx. 2015; 42: 483-7.

5) Piao Y, Wang C, et al. Concomitant occurrence of Mikulicz's disease and immunoglobulin G4-related chronic rhinosinusitis: a clinicopathological study of 12 cases. Histopathology. 2016; 68: $502-12$.

6) Okazaki K, Umehara H. Are Classification Criteria for IgG4-RD Now Possible? The Concept of IgG4-Related Disease and Proposal of Comprehensive Diagnostic Criteria in Japan. Int J Rheumatol. 2012; 2012: 357071.

7) Takano K, Abe A, et al. Clinical Evaluation of Sinonasal Lesions in Patients With Immunoglobulin G4-Related Disease. Ann Otol Rhinol Laryngol. 2015; 124: 965-71.

8) Koyama T, Kariya S, et al. Significance of IgG4-positive cells in severe eosinophilic chronic Rhinosinusitis. Allergol Int. 2019; 68: $216-24$.

9) 塩川雅広, 巟玉裕三.【IgG4 関連疾患 - 診断と治療の最新動 向】 IgG4 関連疾患の自己抗原. カレントテラピー 2020; 58 : 716-9.

10）猪俣啓子, 永淵正法, 他.【甲状腺疾患と IgG4 関連疾患】 IgG4 甲状腺炎に扔ける IgG4 自己抗体の標的抗原の同定. 日 本甲状腺学会雑誌 2019; 10: 40-6.

11）谷口賢新郎, 太田 康, 他. IgG4 関連疾患と思われた難治 性慢性副鼻腔炎の 2 症例。日鼻科 2019; 58: 719-24.

12) Ota $Y$, Ishikawa $F$, et al. A case of refractory chronic rhinosinusitis with anti-desmoglein 3 IgG4 autoantibody. Allergol Int. 2017; 66: 634-6. 